\title{
The Role of Event in Building Brand Satisfaction, Trust and Loyalty of Isotonic Drink
}

\author{
Adi Irianto Marist ${ }^{1}$, Lilik Noor Yuliati ${ }^{2} \&$ Mukhamad Najib ${ }^{3}$ \\ ${ }^{1}$ Business Management, Bogor Agricultural University, Bogor, Indonesia \\ ${ }^{2}$ Lecturer of Consumers and Family Science Department, Bogor Agricultural University, Bogor, Indonesia \\ ${ }^{3}$ Lecturer of Management Department, Bogor Agricultural University, Bogor, Indonesia \\ Correspondence: Adi Irianto Marist, Business Management, Bogor Agricultural University, Bogor, Indonesia. \\ Tel: 62-856-9416-7614. E-mail: adi.marist@gmail.com
}

\author{
Received: August 30, $2014 \quad$ Accepted: September 23, $2014 \quad$ Online Published: November 24, 2014 \\ doi:10.5539/ijms.v6n6p57 URL: http://dx.doi.org/10.5539/ijms.v6n6p57
}

\begin{abstract}
Event is able to communicate the best experience possessed of a brand to consumers so that they are able to recall the brand in a long time that led to the formation of trust, satisfaction and loyalty towards the brand. This study shows that a brand activation event has positive effect on brand trust and brand satisfaction, and brand experiences has positive effect on brand satisfaction and brand loyalty. Affective dimensions of brand in brand experience should be strengthened in an event to make consumers increasingly believe in a brand and promoted to be loyal to the brand. The presence of affective dimensions in brand experience is very influential to strengthen customer confidence in the brand which leads to increase loyalty towards the brand.
\end{abstract}

Keywords: events, brand activation, brand experience, brand satisfaction, brand trust, brand loyalty

\section{Introduction}

Marketing is an important element that can enhance a brand's competitive in the market competition. However, the marketing of food and beverage products is now beginning to face many challenges, especially product of isotonic drink. Vel and Sharman (2010) argued that the marketing of products has begun to pose many challenges because of saturated market conditions, the overwhelming availability of substitutes, and diminishing opportunities for differentiation. In addition, Villa-Lopez and Rodriguez-Molina (2013) suggested that consumers have been saturated with advertising messages in conventional communication media and as a result, they have become hardened to advertising. Based on the angle of view to forming a relationship marketing, brand manager must seek new and innovative ways to creating long-lasting, mutually-benefecial relationship (or bonds) with a most important asset: namely, their customers (Mitchell \& Orwig, 2002).

The relationship can be formed through the communication form of human activity that associated with a lot of people (Kotler \& Keller, 2012). Consumers are considered to have received a marketing communications brand if it has to know the advantages of the branded products so that they buy a product with that brand (Wernerfelt, 1996). Several relationship marketing scholars agree that communication is a fundamental aspect of relationship development (Andersen 2001). Brand activation is able to improve communication to consumers in a better way, increase sales and locate the brand in a certain position that company wanted (Liembawati et al., 2014) and event is one of brand activation form.

Becoming part of a personally relevant moment in consumer's lives through event and experiences can broaden and deepen a company or brand's relationship with the target market (Kotler \& Keller 2012). Appropriate brand communication strategy for the company in communicating important information of the brand is event (Piesiewicz, 2010). Event is often used to allow consumers dealing directly with the brand of a product that is capable of forming a special relationship intensively to make consumers become part of the brand itself (Wenats et al., 2012). Event is the best option to deliver and communicate the best experience possessed of a brand to consumers (Johnson, 2008).

Event is a medium that is applied by marketers as an opportunity to plan and facilitate the brand experience to the consumer (Crowther, 2011). Brand experience is a subjective, internal consumer responses (sensations, feelings, and cognitions) and behavioral responses evoked by brand-related stimuli that are part of a brand's 
design and identity, packaging, communications, and environments (Brakus et al., 2009). Through brand experience, consumers is capable to remember the brand for a long time that led forming trust, satisfaction and consumer loyalty to the brand (Brakus et al., 2009, Chinomona, 2013). Lee and Kang (2012) revealed that brand experience positively able to encourage consumers to trust and commit to a brand that led to the behavior of brand loyalty.

Event that used as the object of this research is a brand activation form of one of isotonic drink brand in Indonesia. This event is intended to provide an opportunity for consumers to contact directly with isotonic drink brand and feel the experience from the brand. Event is expected to educate consumers about the benefits of isotonic drink brands and increase consumer knowledge about the brand. The main theme of this event is to encourage people to move or exercise and understand the importance of body fluids in supporting all their daily activities, especially exercise through this isotonic drink brand. This event was contained with aerobic, selling package of isotonic drink which combined with coupon for games with prizes and doorprize coupon.

This study is trying to explain the relationship of brand experience to brand satisfaction, brand trust and brand loyalty, the relationship among brand activation based on brand experience to brand satisfaction and brand trust, the relationship between brand satisfaction to brand loyalty and the relationship between brand trust to brand loyalty in event that conducted by an isotonic drink brand in Indonesia.

\section{Literature Review}

\subsection{Relationship of Brand Experience with Brand Satisfaction, Brand Trust and Brand Loyalty}

Brand experience is strong predictor of actual buying behavior, which in turn is a better predictor for satisfaction. Brand experience has a behavioral influence, which affects consumer satisfaction and loyalty directly and indirectly through brand personality (Brakus et al., 2009). Positive brand experience will produce positive cognitive and emotional state that led to the psychological satisfaction to the brand (Kim, 2005).

Ha (2004) suggested that the relationships formed between consumers and brand depends on the perceived consumer brand trust after feeling experience with the brand. Consumers who enjoy the affective experience of a brand will feel that the brand can be trusted. When the consumer perceived affective feelings toward the brand increasing, it made the relationship between consumers and the brand be stronger so that they will become increasingly believe in the brand (Lee \& Kang, 2012).

Relationship between brand experience to brand loyalty showed in Brakus et al. (2009) research that brand experience has positive impact to brand loyalty. Iglesias et al. (2011) suggested the relationship between brand experience and brand loyalty was completely mediated by affective commitment and brand experience will lead to true brand loyalty if affective commitment between the brand and its consumer has also been developed. As a result, the following hypotheses are proposed:

H1: Brand experience has positive effect on brand satisfaction.

$\mathrm{H} 2$ : Brand experience has positive effect on brand loyalty.

H3: Brand experience has positive effect on brand trust.

\subsection{Relationship of Brand Activation in Brand Experience Approach with Brand Satisfaction and Brand Trust}

The method used in brand activation is providing a positive experience at the meeting point between brand and consumer, so it means brand experience is an integral component of brand activation (Liembawati et al., 2014). This research uses brand activation in brand experience approach to measure the role of the event. Liembawati et al. (2014) showed that brand activation based on brand experience has a significant and positive effect to brand satisfaction and brand trust. Based on these findings, the following hypothesis is proposed in this study:

H4: Brand activation with brand experience approach has positive effect on brand satisfaction.

H5: Brand activation with brand experience approach has positive effect on brand trust.

\subsection{Relationship of Brand Satisfaction with Brand Trust and Brand Loyalty}

Chinomona et al. (2013) suggested that brand satisfaction has strong influence on brand trust. Higher level of brand satisfaction is associated with higher levels of brand trust (Chinomona, 2013). Brand satisfaction has positive relationship with brand loyalty. Customers who feel more satisfied then will obviously have a high loyalty towards the brand. Marketing managers should maintain customer satisfaction which is strongly related with actual repurchase behavior (Lee \& Lee, 2013). Ismail et al. (2012) proved that the brand satisfaction has a high correlation in forming strong relationship between consumer and brand, which influence consumer loyal behavior to brand. With the recognition of previous discussion, following hypotheses are proposed: 
H6: Brand satisfaction has positive effect on brand trust.

H7: Brand Satisfaction has positive effect on brand.

\subsection{Relationship of Brand Trust with Brand Loyalty}

Brand trust is a secure feeling of brand when it meets consumer expectations (Delgado-Ballester \& Munuera-Aleman, 2001). Taylor et al. (2004) explain that brand trust gives the greatest influence in the formation of brand loyalty. This is also supported from Delgado-Ballester and Munuera-Aleman (2001) that trust is the most important variable in developing a relationship with the customer for a long period, such as brand loyalty. The formation of consumer commitment behavior to a brand that has implications for brand loyalty does not just glued to the formation of a functional relationship of brand satisfaction but also need personal relationship of brand trust (Story \& Hess, 2006). In line with these findings, the study tests the subsequent hypothesis:

H8: Brand trust has positive effect on brand loyalty.

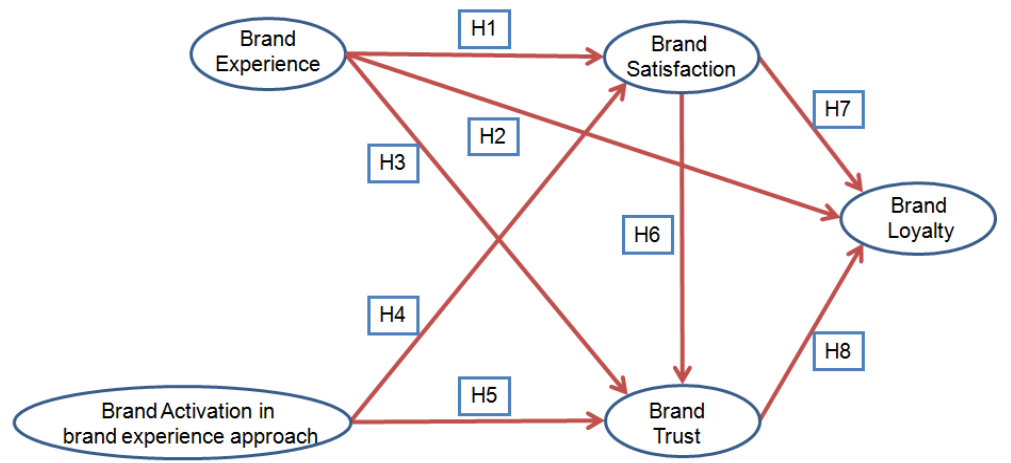

Figure 1. Conceptual framework for the study

\section{Methods}

\subsection{Data Collection}

The data in this study were drawn from two sources, namely primary data and secondary data. Primary data were obtained directly from consumers who follow the event through questionnaires. Secondary data obtained is literature or references that are intended to support research. Primary data is collected through filling questionnaire in five cities of Indonesia: Lampung, Padang, Bandung, Cirebon and Purwokerto which are the venue for the event. The data only talk about brand experience, brand activation in brand experience approach, brand satisfaction, brand trust and brand loyalty after following the event which are the object of research.

\subsection{Measurement}

Respondents are selected by non-probability method of accidential or convenience. This technique do sample collection based on right time, right situation and right place (Prasad and Jannah 2005). The number of samples taken in this study was 454 samples. Form of questions in the questionnaire is the question that the answer already set using 5 -point Likert scale $(1=$ strongly disagree to $5=$ strongly agree). Requirements to be a respondent in filling the questionnaire are:

- Aged 17 years and over (have the ability to make their own decisions when buying)

- Following the event at least twice

- Consuming brand 1-2 times per week in last month

Variables which used in this research are:

a. Independent variables includes brand experience $(\mathrm{M})$ and brand activation in brand experience approach

(E). Indicators of brand experience are (Brakus et al., 2009):

\section{- $\quad$ Sensory (MS)}

MS 1. This brand makes a strong impression on my visual sense or other senses

MS 2. I find this brand interesting in a sensory way

MS 3. This brand appeals to my senses 
- $\quad$ Affective (MA)

MA 1. This brand induces feelings and sentiments

MA 2. I have strong emotions for this brand

MA 3. This brand is an emotional brand

- Behavior (MB)

MB 1. I engage in physical actions and behaviors when I use this brand

MB 2. This brand results in bodily experiences

MB 3. This brand is action oriented

- Intelectual (MI)

MI 1. I engage in a lot of thinking when I encounter this brand

MI 2. This brand makes me think

MI 3. This brand stimulates my curiosity and problem solving

Indicators of brand activation with brand experience approach are (Liembawati et al., 2014):

- $\quad$ Sensory (ES)

ES 1. I find this event interesting in a sensory way

ES 2. I find aerobics interesting in a sensory way

ES 3. I find product package selling interesting in a sensory way

ES 4. I find games with prizes interesting in a sensory way

ES 5. I find change to win doorprize interesting in a sensory way

- $\quad$ Affective (EA)

EA 1. This event is fun and enjoyable

EA 2. This event makes me happy to the brand

EA 3. This event provide an unforgettable experience

EA 4. This event makes me happy to move and exercise

- Behavior (EB)

EB 1. This event makes me more to find out about the brand

EB 2. This event makes me always want to use the brand

EB 3. This event makes me to always want to attend the next event of brand

EB 4. This event inspires me to keep moving and exercising

- Intelectual (EI)

EI 1. This event makes me more understanding about the brand

EI 2. This event makes me more understanding about the importance of body fluid

EI 3. This event makes me more understanding about the importance of moving and exercising

b. Intervening variables are brand satisfaction (PUAS) and brand trust (PCY).

Indicators of brand satisfaction are (Liembawati et al., 2014, Chinomona et al., 2013):

PUAS 1. I am very satisfied with the product quality of the brand

PUAS 2. The price of brand product is comparable with the quality offered

PUAS 3. I am very satisfied with the brand

PUAS 4. I am happy with the brand

PUAS 5. I made the right decision when I decided to use this brand.

Indicators of brand trust are (Liembawati et al., 2014, Chinomona et al., 2013):

PCY 1. The brand is never disappointing 
PCY 2. The brand is quality assured

PCY 3. The brand is safe

PCY 4. The brand is my top choice to rehydrate my body fluid

PCY 5. The brand provide benefits in accordance with the promised

c. Dependent variable is brand loyalty (LOYAL). The indicators of brand loyalty are (Brakus et al., 2009, Chinomona et al., 2013):

LOYAL 1. I am not interested to use other brand beside this brand

LOYAL 2. I am willing to recommend this brand

LOYAL 3. I intend to keep purchasing this brand

\subsection{Data Analysis}

The data analysis technique used in this study is Structural Equation Modeling (SEM) and cross-tabulation analysis. SEM method is the development of path analysis and multipleregression which is equally a form of multivariate analysis model. In general, SEM can be used to analyze the research model that has multiple independent variables, dependent variables and moderating or intervening variables (Haryono \& Ward, 2012). SEM is able to estimate the relationship between variables that are a multiple relationship and describe relationship of social variables that generally can not be measured directly (latent) (Liembawati et al., 2014). Hair et al. (2006) suggested that SEM can identify relationships between latent construction such as identifying the relationship between the independent and dependent variables in a multiple regression analysis and SEM is the best step in identifying empirically the theoretical model involving both measurement models and structural models in a single analysis. Indratno and Irwinsyah (1998) explain that a cross-tabulation analysis is used to look relationship between variables or factors and obtain the degree of linkage or association between variables or factors were measured.

\section{Result}

\subsection{Descriptive Statistics}

Respondents were taken from five citis which are the event ongoing: Lampung (12\%), Padang (25\%), Bandung (7\%), Cirebon (33\%), and Purwokerto (23\%). Largest number of respondents came from Cirebon. Characteristic of respondents by age is divided into four age categories: $17-30$ years $(67 \%), 31-40$ years $(27 \%), 41-50$ years $(5 \%)$ and above 50 years $(1 \%)$. For the marital status of respondents, most of respondents $(50 \%)$ were married, $48 \%$ of respondents were single and $2 \%$ of respondents were widows and widowers. Regarding their education level, $61 \%$ of respondents were senior high school degree, $18 \%$ of respondents were graduate degree, $12 \%$ of respondents were bachelor degree and $9 \%$ of respondents were junior high school. Based on their occupation, first place was student (27\%), second place was entrepreneur (18\%), third place was hounsewives $(15 \%)$, civil servants at the fouth place $(12 \%)$ and other $(1 \%)$. The behavior of respondent in purchasing the brand was consisted in roadside stalls (45\%), in store or retail (40\%), in supermarket (14\%) and other (1\%).

\subsection{Goodness of Fit Model}

The model of this research should be evaluated by goodness of fit analysis. This analysis is intended to determine the model can be trusted or not. Goodness of fit analysis of the model that used are the root mean square residual, root mean square error of approximation, the goodness of fit index, adjusted goodness of fit index, comparative fit index, and the normed fit index. The results of the analysis of the suitability of the model can be observed in Table 1 and all values of goodness of fit analysis of the model are good fit.

Table 1. Goodness of fit analysis

\begin{tabular}{llll}
\hline Goodness-of-Fit & Cutt-off-Value & Result & Description \\
\hline RMSR(Root Mean Square Residual) & 0,05 atau 0,1 & 0.048 & Good Fit \\
RMSEA(Root Mean square Error of Approximation) & 30,08 & 0.043 & Good Fit \\
GFI(Goodness of Fit) & 30,90 & 0.98 & Good Fit \\
AGFI(Adjusted Goodness of Fit Index) & $\geq 0,90$ & 0.95 & Good Fit \\
CFI (Comparative Fit Index) & $\geq 0,95$ & 0.98 & Good Fit \\
NFI (Normed Fit Index) & & 0.97 & Good Fit \\
\hline
\end{tabular}




\subsection{Structural Equation Model}

Brand experience has positive effect on brand satisfaction (0.12). Hypothesis 1 is considered significant because |t-statistics| of this hypothesis is 2.32 (bigger than t-table 1.96). Beside that, brand experience has positive effect on brand loyalty (Hypothesis 2) with the value of path coefficient is 0.60 . The |t-statistics| of Hypothesis 2 is higher too from t-table 1.96 (10.41). However, result of Hypothesis 3 is different from Hypothesis 1 dan 2. Based on this result, brand experience has negative effect on brand trust $(-0.20)$. Value of Hypothesis 3 $|t-s t a t i s t i c s|$ is 4.38 , it shows that the negative effect between brand experience and brand trust is significant.

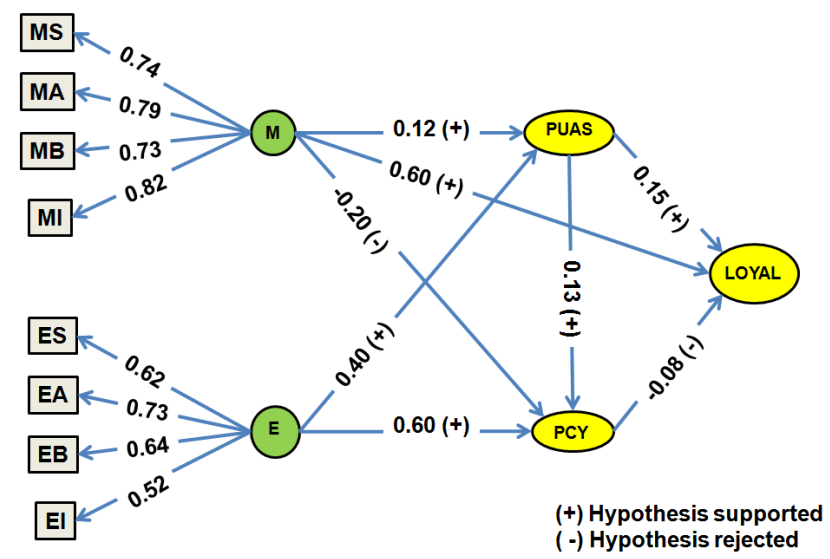

Figure 2. Structural model result

Relationship of brand activation in brand experience approach with brand satisfaction has positive effect $(0.40)$, it is based on |t-statistics| value of Hypothesis 4 is 6.53 (higher than t-table 1.96). Hypothesis 5 is supported (|t-statistics $\mid$ is 7.31), it means brand activation in brand experience approach effect brand trust $(0.60)$. Comparing path coefficient between Hypothesis 4 and 5, relationship of brand activation in brand experience approach with brand satisfaction has higher effect than relationship of brand activation in brand experience approach with brand trust.

Table 2. Results of structural equation model analysis

\begin{tabular}{lllll}
\hline Path Relationship & Hipotesis & Path Coefficient & $\mid$ T-Statistics $\mid$ & Results of the test \\
\hline Brand experience $\rightarrow$ Brand satisfaction & H1 & 0.12 & 2.32 & Supported \\
Brand experience $\rightarrow$ Brand loyalty & H2 & 0.6 & 10.41 & Supported \\
Brand experience $\rightarrow$ Brand trust & $\mathrm{H} 3$ & -0.2 & 4.38 & Rejected \\
$\begin{array}{l}\text { Brand activation in brand experience } \\
\text { approach } \rightarrow \text { Brand satisfaction }\end{array}$ & $\mathrm{H} 4$ & 0.4 & 6.53 & Supported \\
Brand activation in brand experience approach & & & & \\
$\rightarrow$ Brand trust & $\mathrm{H} 5$ & 0.6 & 7.31 & Supported \\
Brand satisfaction $\rightarrow$ Brand trust & $\mathrm{H} 6$ & 0.13 & 2.72 & Supported \\
Brand satisfaction $\rightarrow$ Brand loyalty & $\mathrm{H} 7$ & 0.15 & 3.27 & Supported \\
Brand trust $\rightarrow$ Brand loyalty & $\mathrm{H} 8$ & -0.08 & 1.64 & Rejected \\
\hline
\end{tabular}

Result of Hypothesis 6 show brand satisfaction has positive effect on brand trust $(0.13)$ with $\mid t$-statistics $\mid$ is 2.72 $(>1.96)$. Then the resulf of Hypothesis 7 is supported too, it means brand satisfaction has positive effect on brand loyalty (0.15) with |t-statistics $\mid$ is 3.27 (> 1.96). Effect of brand satisfaction to brand trust is higher than effect of brand satisfaction to brand loyalty. Result of Hypothesis 8 is rejected because the $\mid t$-statistics $\mid$ is 1.64 $(<1.96)$. The path coefficient of this hypothesis is -0.08 , it shows brand trust has negative effect on brand loyalty. 
Table 3. Cross-tabulation analysis

\begin{tabular}{llllllllll}
\hline $\begin{array}{l}\text { Consumer } \\
\text { Behavior }\end{array}$ & \multicolumn{3}{c}{ Brand Satisfaction } & \multicolumn{3}{c}{ Brand Trust } & & Brand Loyalty \\
\hline & Chi-square & Probability & Result & Chi-square & Probability & Result & Chi-square & Probability & Result \\
\hline $\begin{array}{l}\text { Destination to } \\
\text { consume the } \\
\text { brand }\end{array}$ & 17,984 & 0,006 & Significant & 7,896 & 0,545 & $\begin{array}{l}\text { Not } \\
\text { Significant }\end{array}$ & 30,371 & 0,000 & Significant \\
\hline $\begin{array}{l}\text { Condition } \\
\text { when } \\
\text { consuming the } \\
\text { brand }\end{array}$ & 36,652 & 0,000 & Significant & 48,936 & 0,000 & Significant & 34,228 & 0,001 & Significant \\
\hline $\begin{array}{l}\text { Reason to } \\
\text { choose the } \\
\text { brand }\end{array}$ & 14,457 & 0,025 & Significant & 22,731 & 0,007 & Significant & 41,551 & 0,000 & Significant \\
\hline
\end{tabular}

Cross-tabulation analysis in this study is intended to determine the effect of consumer behavior on destination to consume the brand, condition when consuming the brand, and reason to choose the brand than any other brand to brand satisfaction, brand trust and brand loyalty. Consumer behavior on condition when consuming the brand and reason for choosing the brand than other brands significantly influence brand satisfaction, brand trust and brand loyalty. In contrast, the consumer behavior on consuming destination of the brand only has significant effect on brand loyalty and brand satisfaction, but not significant effect to brand trust.

\section{Discussion and Conclusion}

This research proves the statement of Liembawati et al. (2014) that brand activation like event in brand experience approach (dimensions of sensory, affective, behavioral and intellectual) has positive effect on brand satisfaction and brand trust. Brand experience that consumers felt through event can increase brand satisfaction and brand trust. The event held by the brand is clearly able to drive satisfacton and trust toward the brand which do the event. When seeing from viewpoint of brand activation in brand experience approach, consumers will be satisfied and belief toward the brand, but by seeing from viewpoint of the brand itself, it's different. It's showed from the result of Hypothesis 3 and 8 .

Result of Hypothesis 3 shows brand experience has negative effect to brand trust. This result is different with the research of Chinomona (2013) that said brand experience has positive effect to brand trust. Lee and Kang (2012) suggested behavioral brand experience leads consumer itu behavioral and physical responses so that brand trust may be less related to the behavioral brand experience. The behavioral dimension means when a consumer uses a brand, it makes the consumer physically active (Lee \& Kang, 2012) and includes bodily experiences, lifestyles and interaction with brand (Zarantonella \& Schmitt, 2010). Relationship between brand experience and brand trust will be more positive if affective dimension increase. Lee and Kang (2012) said consumer who enjoy greater affective brand experience thinks that the brand is more trustful and the relationship between consumer and brand will be strengthened and come to trust the brand when consumer feel brand are affective. If the consumer can enjoy greater both affective and behavioral dimension of brand experience, the commitment between consumer and brand also highly increases (Lee \& Kang, 2012).

Negative effect of brand experience to brand trust also influence relationship of brand trust and brand loyalty (Hypothesis 8). This incompatibility is confirmed by the result of cross-tabulation analysis (Table 3). This analysis shows the connection between consumer behavior in destination to consume the brand and brand trust is not significant. Chaudhuri and Holbrook (2001) defined brand trust as most consumer desire to rely on the ability of the brand in performing its stated function. In other words, consumers who believe in a brand and want to buy the brand because they want the needs or goals that customer owned are met by the capabilities of the brand. Consumers who believe will loyal and willing to buy a brand at a premium price (Alam \& Yasin, 2010).

This study show brand experience has negative effect to brand trust but has positive effect to brand satisfaction and brand loyalty. In this research, the positive effect of brand experience to brand loyalty is bigger than brand experience to brand satisfaction. This result is same like Brakus et al. (2009) research that showed the direct effect of experience on loyalty is higher than direct effet of experience on satisfaction. Brand experience has a greater influence on brand loyalty compared to brand satisfaction because of the similarity between the dimensions of brand experience (dimensions think, feel and act) on brand loyalty (cognitive, affective, conative (behavioral intention) and action) (Nysveen et al., 2013). 
The event is an excellent medium in increasing satisfaction, trust and loyalty brand, especially isotonic drinks brand. Event is able to provide experiences that encourage consumers to be more satisfied, trusting and loyal to the brand. Regardless of the success of an event, marketers should also pay attention to the existence of the brand itself in the event. Brands featured in the event must be able to drive satisfaction, trust and loyalty to the brand.

\section{Implication and Limitation}

\subsection{Managerial Implications}

The event was conducted by isotonic drink brand has positive effect on consumer confidence and satisfaction towards the brand. This event have performed and accepted by consumers well. But this event remains to be further developed, especially increasing affective brand experience in event. Affective dimension of brand experience is clearly able to grow the brand trust that implies a commitment to be loyal to the brand. Combination of affective and behavioral brand experience is needed to improve relationship between consumers to the brand. Brand loyalty is formed from brand satisfaction and brand trust and can't be focused only on brand activation but should also focus on building the brand itself in the eyes of consumers through brand experience such as event.

\subsection{Limitations}

This study has several limitations. First, the study was only done on one particular brand that is one of isotonic drink brand in Indonesia. Second, this study only took respondents from five cities as targets of research, whereas events held by the brand took place in 15 cities in Indonesia. Third, the presence of other variables not measured in this study that can influence respondent's assessment of the brand because respondents do not only get information about a brand by following the events but can also get information from other media such as television advertisements, radio or word of mouth.

\section{References}

Alam, S. S., \& dan Yasin, N. M. (2010). What factors influence online brand trust: evidence from online tickets buyers in Malaysia. Journal of Theoretical and Applied Electronic Commerse Research, 5(3), 78-89. http://dx.doi.org/10.4067/S0718-18762010000300008

Andersen, P. H. (2001). Relationship development and marketing communication: an integrative model. The Journal of Business and Industrial Marketing, 16(3), 167-182.

Brakus, J. J., Schmitt, B. H., \& Zarantonello, L. (2009). Brand experience: What is it? How is it measured? Does it affect loyalty? Jounal of Marketing, (73), 52-68.

Chaudhuri, A., \& dan Holbrook, M. B. (2001). The chain of effect from brand trust and brand affect to brand performance: Th role of brand loyalty. Journal of Marketing, 65(2), 81-93.

Chinomona, R. (2013). The influence of brand experience on brand satisfaction, trust and attachment in South Africa. International Business and Economics Research Journal, 12(10), 1303-1316.

Chinomona, R., Mahlangu, D., \& Pooe, D. (2013). Brand service quality, satisfaction, trust and preference as predictors of consumer brand loyalty in the retailing industry. Mediterranean Journal of Social Sciences, 4(14), 181-190. http://dx.doi.org/10.5901/mjss.2013.v4n14p181

Crowther, P. (2011). Marketing event outcomes: from tactical to strategic. International Journal of Event and Festival Management, 2(1), 68-82. http://dx.doi.org/10.1108/17582951111116623

Delgado-Bellester, E., \& dan Munuera-Aleman, J. L. (2001). Brand trust in the context of consumer loyalty. European Journal of Marketing, 35(11/12), 1238-1258.

Ha, H. (2004). Factors influencing consumer perceptions of brand trust online. The Journal of Product and Brand Management, 13(4/5), 329-342. http://dx.doi.org/10.1108/10610420410554412

Hair et al. (2006). Multivariate Data Analysis (6th ed.). USA: Pearson Prentice Hall.

Haryono, S., \& dan Wardoyo, P. (2012). Structural Equation Modeling untuk Penelitian Manajemen Menggunakan AMOS 18:00. Bekasi: Intermedia Personalia Utama.

Iglesias, O., Singh, J. J., \& Batista-Foguet, J. M. (2011). The role of brand experience and affective commitment in determining brand loyalty. Journal of Brand Management, 18(8), 570-582. http://dx.doi.org/10.1057/bm.2010.58

Indratno, I., \& Irwinsyah, R. (1998). Aplikasi analisis tabulasi silang dalam perencanaan wilayah dan kota. Jurnal PWK, 9(2), 48-59. 
Ismail, R., Boye, C. L., \& Muth, A. (2012). Customer brand relationship: An empirical study of customer's perception of brand experience, brand satisfaction, brand trust and how they affect brand loyalty. Marketing Program, Linnaeus University.

Johnson, C. (2008). Event marketing or product sampling? Journal of Consumer Marketing, 25(5), 269-271. http://dx.doi.org/10.1108/07363760810890499

Kim, H. S. (2005). Consumer profiles of apparel product involvement and values. Journal of Fashion Marketing and Management, 9(2), 207-220. http://dx.doi.org/10.1108/13612020510599358

Kotler, P., \& dan Keller, K. L. (2012). Marketing Management. London: Pearson.

Lee, H. J., \& dan Kang, M. S. (2012). The effect of brand experience on brand relationship quality. Academy of Marketing Studies Journal, 16(1), 87-98.

Lee, J., \& dan Lee, H. (2013). Does satisfaction affect brand loyalty? Academy of Marketing Studies Journal. 17(2), 133-147.

Liembawati, Y., Dharmayanti, D., \& Brahmana, R. K. M. R. (2014). Analisa pengaruh brand activation terhadap pembentukan brand community pada PT. ISM Bogasari Flour Mills. Jurnal Manajemen Pemasaran Petra, 2(1), 1-15.

Mitchell, M. A., \& dan Orwig, R. A. (2002). Consumer experience tourism and brand bonding. The Journal of Product and Brand Management, 11(1), 30-41. http://dx.doi.org/10.1108/10610420210419531

Nysveen, H., Pedersen, P. E., \& Skard, S. (2013). Brand experience in service organizations: exploring the individual effects of brand experience dimensions. Journal of Brand Management, 20(5), 404-423. http://dx.doi.org/10.1057/bm.2012.31

Piesiewicz, J. (2010). Event marketing takes center stage. Communication World, 27(1), 40-41.

Prasetyo, B., \& dan Jannah, L. M. (2005). Metode Penelitian Kuantitatif Teori dan Aplikasi. Jakarta: Raja Grafindo Perkasa.

Story, J., \& dan Hess, J. (2006). Segmenting customer-brand relations: beyond the personal relationship metaphor. Journal of Consumer Marketing, 23(7), 406-413. http://dx.doi.org/10.1108/07363760610712948

Taylor, S. A., Celuch, K., \& Goodwin, S. (2004). The importance of brand equity to customer loyalty. The Journal of Product and Brand Management, 13(4/5), 217-227. http://dx.doi.org/10.1108/10610420410546934

Vel, K. P., \& dan Sharma, R. (2010). Megamarketing an event using integrated marketing communications: the success story of TMH. Business Strategy Series, 11(6), 371-382. http://dx.doi.org/10.1108/17515631011093070

Vila-Lopez, N., \& dan Rodriguez-Molina, M. (2013). Event-brand transfer in an entertainment service: experiential marketing. Industrial Management and Data System, 113(5), 712-731. http://dx.doi.org/10.1108/02635571311324160

Wenats, A. E. et al. (2012). Integrated Marketing Communications. Jakarta: Gramedia.

Wernerfelt, B. (1996). Efficient marketing communication: Helping the customer learn. Journal of Marketing Research, 33(2), 239-246.

Zarantonello, L., \& Schmitt, B. H. (2010). Using the brand experience scale to profile consumers and predict consumer behavior. Journal of Brand Management, 17(7), 532-540. http://dx.doi.org/10.1057/bm.2010.4

\section{Copyrights}

Copyright for this article is retained by the author(s), with first publication rights granted to the journal.

This is an open-access article distributed under the terms and conditions of the Creative Commons Attribution license (http://creativecommons.org/licenses/by/3.0/). 